\title{
Shamanistic Practice in Northern Nepal
}

\author{
by TONI SCHMID
}

My experience of shamanistic practice was gained primarily during a stay of several months among the Sherpas of Northern Nepal. The region concerned is now called "Helembo" or "Helambo", and is identical with the "Yol-mo" named in the "Hundred Thousand Songs" of the Tibetan poet Milaraspa (pronounced Milaräba).

The Sherpas-in Tibetan sar-pa or "men of the east"-live mainly in Northern Nepal, in the Darjeeling district, in India and Northern Sikkim, in the regions bordering on Tibet, and on the southern slopes of the Himalayas. As a rule they dwell as high as possible in the mountains where the means of livelihood are negligible, apart from tamang and limbu. In Helembo some of them lead a partly nomadic life, such as, mutatis mutandis, was still being led a few decades ago in parts of Härjedalen. They follow their cattle to the pastures, and at certain periods visit other areas affording means of subsistence, where for example they can collect sug- $p a$.

The Sherpas are of Tibetan stock. Among the Tibetan racial groups two religions can be broadly distinguished. One is a form of Buddhism, usually called Lamaism. The other religion is called in the Lhasa pronunciation Bön. Among the Sherpas both the religion and its priests are called "bombo", spelt: bon-po.

Lamaism has a variety of sects or orders, as they may be called, some older, others more recent, ranging from "The Old Sect", believed to have been founded in the 8th Century by King Khri-sron-lde'u-bcan's (pronounced Ti-song-de-tsän) contemporary Padmasambhava, to the "Yellow Hats" (žva-ser) or "Virtuous Order" (dge-lugs-pa) instituted by the reformer bCon-kha-pa about 1400 . In the land of the Sherpas there also exist some Karma-pas, but above all "The Old Sect"-Tib. rñin-ma (pronounced njing-ma) order. Their High Lama receives a tribute dating from the time 
of the first and true ancestor "Chinalama" (pronounced Tjinyalama), whose title he still bears. Padmasambhava occupies a prominent position in the temple, and is usually flanked by two wives. Usual also are the dark-red Buddha Amitābha (Tib. 'Od-dpag-med, pronounced ö-pā-me), the white Avalokiteśvara (Tib. sPyan-ras-gzigs, pronounced Tjän-rä-si) with four arms, and the dark-blue Vajrapāni (Tib. Phyag-na-rdo-rje, pronounced Tjā-nado(r)-je).

The inhabitants also embrace bön. This does not lead to any division in their society. On the contrary, the same people attend both the Buddhist temple and the bön ceremonies. Even the lamas and the bön priests are in no way hostile towards each other. I have seen bön priests and their families taking part in the che-rin festival in the Buddhist temple, and I have seen the lama's household - though not the lamas themselves-attending ceremonies conducted by a bön priest. On certain occasions a bön priest officiated in a lama's home, and before his relatives. On the other hand, the lama carried out the ritual of the dead at a cremation (compulsory in Nepal) for all and sundry, even for bön priests. The only ones not to be cremated were small children. According to report their corpses were pushed under a rock.

$B o m b o$ is the name for the belief and the priest, and Bombo-SE, Tib. bonpo gsos (Bön is life), is the chorus to the best-known bön hymn, sung even by the lama's children. However it is debatable whether this has any connection with bön-belief or bön-cult.

Along with Professor Matthias Hermanns who spent many years among the Tibetans in Amdo, several scholars have distinguished not two but three religions among the peoples of Tibetan stock. They distinguish between Lamaism, bön and primitive shamanism. In Kumbum Dschamba Ling ( 17 ) Wilhelm Filchner compares bön in Tibet with shamanism in Mongolia. René Wojkowitz-Nebesky, who died some years ago, considered that the so-called bön among the Sherpas was not bön but rather a pure form of primitive shamanism. I shall try to describe the little I have seen of it.

None of the bön priests that I have met have been so to speak 'full-time' priests. They were married, had a house, arable land and domestic animals; some also had children. To all appearances they were highly esteemed, and not poor. They all seemed to be noticeably above average in intelligence, but 
could neither read nor write. They had no books. In this respect they differ from even the poorest village lamas in the region and from the bön priests who live in monasteries and possess literary collections. They also differ, for example, from the shamans described by Professor Rintchen in his latest book, in which he maintains that the shamans use books.

In their daily lives and customary dress they are like the rest of the inhabitants, and like many of the lamas. They wear 'jodhpurs' and the Nepal jacket, and when needed a boko, an almost water-proof coat made generally of white hand-woven woollen cloth, often with decorative stitching. They wear the same jewelry as the peasants, mostly necklaces of coral and turquoise, very large smooth stones, also amber, and the highly-prized twocoloured onyx in oblong pieces. Unlike the lamas they were unshaven, and in their waist-belts they carried khukhri, the curved knife now the most common throughout Nepal. They resemble almost all the inhabitants in being bilingual, speaking Nepalese as well as the Sherpa dialect.

The ceremonial dress is unlike that of the lamas, the Newar priests or the Hindu ascetics who are to be seen making their way to "The Holy Water" (Gosainkunda). I brought back with me a complete outfit of a bön priest's clothes, which is now in the State Ethnographical Museum in Stockholm. It is comparatively simple. It consists of a wide gown made of strong white cotton, with long wide sleeves, and reaching to the ground. It is fastened at the middle with a belt. The head-dress is also of cotton, a kind of turban wound in three colours: white, red and blue. No shoes are worn; the bombo walks and dances bare-foot. Around the neck he wears one or more rosaries of large pointed beads, similar to those used by the Hindus, and which can be bought in Kathmandu, Benares and other Indian towns. Belonging to his equipment are a drum, a necklace of bells and an antelope horn.

The drum is larger than the lamas' hand-drums used during their services. It keeps its natural colour, and is not green like those of the rNinmalamas. It has a handle and is played with the fingers. It has skin at both ends like the great lamaical temple-drums, but no grip as on the Tuva-drums recently described by Diószegi Vilmos (in Acta Ethnographica, tom. xi, fasc. $\mathrm{I}-2, \mathrm{I} 43 \mathrm{ff}$.) The necklet of bells is rather large. It hangs round the neck and is set in motion by the shaking of the body during ecstasy. The horn is fastened to the back. These antelope-horns are said to be imported from Tibet. 
Occasionally it is possible to hear lamas-especially the High Lama at Melamchi (rmi-lam-bčas) - complain that the 'bombo' was always the first to be summoned in the event of illness, child-birth or other emergencies. When the Lama's principal wife lay ill with gall-stone, every effort was made to cure her. A pious and literate Buddhist who acted as a sort of churchwarden at the Gomba (the usual word among Sherpas for a temple, not, as generally, for a monastery, Tib. dgon-pa) read the scriptures by the light of a butterlamp. A European doctor, who was present with me at this place, tended her. A masseur was then summoned-the Sherpas are expert in various sorts of massage-and there arrived a bombo. This bombo lived nearby in a summer-goré, and was a friend of the family. The wife concerned was born in the area, and was particularly esteemed there.

In this region the bombo has no temple, nor does he have an equivalent to the mobile religious tent described by Marion $\mathrm{H}$. Duncan (The Yangtze and the Yak, 1952, 82). They perform their ceremonies out in the open, or in caves, or in the homes to which they are called.

On the above-mentioned occasion the bombo was in full dress. He sat by himself in a corner of the big room on the first floor, that served also as living-room, reception-room, and bed-room for the lama and his household. The butter-lamp was lit, and incense made from sug-pa that grows high up in the mountains was burnt. The bombo recited in a sing-song voice long texts that seemed to be almost entirely litanies and mantras. It was not a repetition of the self-same text, but different texts. We learnt from the lamas that they 'are made up and arranged according to the occasion', in contrast with the holy books of the lamas. But certain texts were said to be transmitted from teacher to novice. 'The profession of bombo' is not inherited, although a son may succeed his father if he possesses the suitable qualifications. Memory-training evidently forms part of the instruction. I received a clear notion of how far such instruction could go even today in Gangtok, in December, 196I. A group of young lama candidates-the youngest only sixteen years old-were made to demonstrate among other things that they had learnt to recite a whole book by heart. The demonstration was carefully supervised by several lamas. None of the candidates faltered once.

The bombo invokes a variety of divinities and spirits. Among the most important are the 'masters of the ground' (Tib. gži-bdag). They seem to be 
related to the 'vittra' of the Lapps, described among others by Björn Collinder, and to the ' $r a$ '. The Sibdag who preside over the place where the ceremony is held are called dam-čan-jo-bo-phya-ti, and are said to be for the most part dangerous. The local gods do not like noise or disturbance; they prefer peace and quiet. Another of the divinities invoked by the bombo was spelt out by a lama as: čhos-kyon-dpos-kar-rgyal-bu (tjö-kyong-pö-kar-djal-bu). The Sherpas often spell according to the pronunciation. It is recognized that King (Tib. rgyal-po) Pekar is spelt in different ways. In Tibet he is renowned as an oracular god, and is incarnated in the monastery gnas-chun, in the vicinity of Lhasa. Also among those invoked was the "Mountain Queen", spelt by one of the lamas as jo-mo-yan-ri-rgyal-mu. The bombo in addition invokes his father's and his grandfather's spirits.

The recitation proceeded at a quickening tempo. To begin with it was ac-. companied by a gentle rhythmic movement of the upper part of the body. The man sat cross-legged. Now he began to twitch and shake. As he shook the bells around his neck started to sound. This lasted rather a long time. After that the ceremony was concluded somewhat abruptly. The man appeared to be exhausted, and soon left the farmstead. This bombo's name was gyu-rgyal or turquoise king.

The curing of illness was one of his and his colleagues' principal concerns. They are said to have a good knowledge of medicinal herbs; one of them was taken by people ill with fever.

The bombo's big day came with the full moon; during my visit it fell on the $3^{\text {rd }}$ of August in the middle of the monsoon-season. There are two types of bombo, those "who cut", that is, kill animals, and those "who do not cut". He belonged to the first type, and on the previous evening had offered up a bowl of "gtor-ma" and hen's blood, and in a state of possession had thrown it over the steep cliff. On the day of the full moon even he was not allowed to slaughter. With his following of young men and women he occupied the 'Wash-house', that formed an extension to the lama's farm-building, where on other occasions different sorts of chan were prepared. Now some images of the gods, or rather symbols, were propped against the wall. Drumming went on without cease.

No lamas take part, but the local inhabitants participate and the bombo's closest assistants are the same as normally assist at the Buddhist temple. 
Two bombos, a girl with a red and white cloth on her breast, and two boys dressed as girls are the foremost participants. An egg was balanced on the drum for as long as possible. Led by the bombos they all danced in a long procession up to a gži-bdag cave which was difficult of access and overlooked a steep drop down to the stream. Short verses were sung, mostly to the same melody with the chorus already mentioned: "Bombo Se". Written out in the Sherpas' own spelling, one of the verses runs thus:

kar po la chog kar chog na mi pu la rgya či bab son la sas 'o las bom bo sos //

and another:

$$
\begin{aligned}
& \text { 'od sken phrom mad čhe sa med sken ñams sa } \\
& \text { kyoñ sa la sos } \\
& \text { 'o las bom bo sos // }
\end{aligned}
$$

Nothing of the full moon was seen. For the fourth day running it had rained. In the dark cave there were some stone sculptures, and also some ochre which people rubbed on their faces.

On one occasion the impression given was that a bombo served almost as a chaplain to the High Lama. Immediately before embarking on a journey down to the Kathmandu district he sacrificed a small black hen to ensure that the journey went well. The sacrifice was performed out of doors, on a flat stone, behind which a raised stone was placed. Strips of cloth were hung on a bush. The bird was killed with a swift stroke of the khukhri.

Bombos are recognized as 'spiritual leaders', recognized even by lamas. This can have economic consequences. When a bombo lost a valuable animal during an epidemic among his cattle, neither the meat, skin or horn was allowed to be saved, but the whole corpse had to be buried. A collection started on his behalf was widely supported. The religious tolerance of these people is demonstrated by the diversity of cultic objects that appear together on an altar. An extremely dangerous Sibdag had its abode close to a Milaraspa cave. The particularly good relations between the lamas and the bombo undoubtedly depended to a large extent on the fact that the great majority of the lamas belonged to the Old Sect. One met nothing like the same tolerance and good-will in Darjeeling and the Kalimpong district. But the Old Sect and the bombos have many points in common and similar practices. 
The lamas had a ritual for bringing on rain, and one to make the rain stop. They had spells and amulets against ailments. They also performed the full moon celebrations, and during these I received the following commentary on the ceremony:

"When Padmasambhava killed the devils he sacrificed his (g)tor-ma (cones of either dough or rice) along with their blood to Buddha. In memory of this, sacrifices are now made on Padmasambhava's command." On the sacrificial dish were red-coloured cam-pa gtor-ma together with roasted beans, maize and 'Nepal apples', also dried meat and earth-nuts. The red colour, 'the blood' was made from a plant called $(s) k o-m a$ in the Sherpa dialect and Smug-rci in Tibetan.

In addition, the lamas attempted to exorcise bhut, ghosts or hostile spirits, which also belong to the bombo's field of activity. When a person after a long period of illness had partially regained his strength, an image of dough was made. It was painted, dressed up, and many gifts were bestowed on it. Afterwards it was carried out of doors, and thrown over a steep cliff towards the stream. It was said that the 'pointless chatter' that went on during the period of the illness disappeared with the image of dough. Such imagesthis was not the only one I had occasion to admire and whose manufacture I had investigated - bore witness like so much else to the artistic talent of the Sherpas. By simple means they arrived at a tolerable likeness. Both the lamas and the bombos were without exception clever with their hands. They could sing, carve in wood, make drums and attractive clothes. Their gtor-ma of dough and their sculptures in butter set on wooden bases were particularly well-done and tastefully coloured. To see a bombo and his followers dancing on an early morning in a sloping meadow was a beautiful experience.

The most obvious testimony to the good relations between the ancient native religions-by these I mean Lamaism's different branches and bomboshamanism as well as Hinduism, but not Christianity (which so far has been only a foreign phenomenon in Nepal), nor Modern Buddhism (whose followers have established a school at Svayambhunath and missionaries in other areas)-is to be found at Bauddha the great stupa about three miles from Kathmandu.

Bauddha is an ancient Buddhist sanctuary, a celebrated pilgrimage-centre for Tibetans, and different legends exist concerning its founding. It is 
believed to contain among other things the relics of the immediate forerunner there of Gautama Buddha, Kasyapa Buddha. Over a long period while living in a building close to Bauddha, I was able to follow all the religious services at the small chapel of the protective divinity at the entrance, and also in the temple opposite, as well as the ritual circumambulation around the stupa performed by pilgrims and local people, during which the large prayer-wheels placed in the wall were set in motion. One morning about four o'clock there appeared a bombo among the other devotees. He was in full dress, with the horn on his back and drum in hand. He circled the stupa in Buddhist fashion with his right side turned towards the holy objects. Consequently he did not walk in the true bon-po fashion with his left side turned towards the objects. Strictly speaking he did not walk, he danced. He danced two or three steps, twirled about, and proceeded in this manner to make several turns around the stupa.

To close I should like to say that with respect to shamanism an investigation into the ancient district of Yol-mo would be well worthwhile. Primarily such an investigation should concern itself with the so-called bombos, but even so the rñin-ma- lamas there with their numerous shamanistic features might also be included. If anyone should organize an investigation such as this, it had better be soon, before the changes that are increasing on all sides obliterate the ancient belief and the traditional practices. 